\title{
Correlations of the Gel Strength of Paste Walls and the Shelf Life of Electric Dry Cells
}

\author{
By Walter J. Hamer
}

\begin{abstract}
Paste walls of most dry cells consist of starch-flour gels. Their characteristics were studied by means of gel-strength measurements and correlated with the shelf life of dry cells. Interactions were observed between the paste wall and the dry-cell electrolyte and the depolarizing mix of manganese dioxide. Attempts were made to eliminate or retard these reactions. These included the use of addition agents, of different varieties of starches and flours, of modified starches, and of fractions of natural starch and natural flour. Only the flour fractions, gliadin and mesonin, in different states of polymerization were found to give an increase in the electrical output of dry cells. No significant differences were found in the electrical output of dry cells made with different starches, and the use of modified starches and starch fractions decreased the electrical output of dry cells. The beneficial effects of the flour fractions were attributed to their action in curtailing the local action at the zinc anodes of dry cells.
\end{abstract}

\section{Introduction}

One of the reasons advanced for the decreased shelf life of electric dry batteries at high temperatures is the deterioration of the paste wall, or its interaction with various constituents of the cell. A Leclanché dry cell consists of a zinc positive element, a carbon negative element surrounded by a depolarizing mix of manganese dioxide, and a paste-wall separator usually consisting of starchflour gels. An electrolyte of saturated ammonium chloride with low concentrations of zinc chloride is generally used. Acetylene black is added to the depolarizing mix to render it more conducting and absorptive. ${ }^{1}$

Otto, Vinal, and Ostrander $[1]^{2}$ have shown by digestion experiments that the paste walls of dry cells react with the depolarizing mix of manganese dioxide. As digestion experiments cannot be used to determine the rate of duration of the interaction, another method, such as the measurement of gel strength, must be used for this purpose. One of the purposes of this paper is to show how gel-strength measurements may be

${ }^{1}$ For a description of a Leclanché dry cell, including a diagram, see E. Otto C. K. Morehouse, and G. W. Vinal, Trans. Electrochem. Soc. Preprint $90-17,235$, (1946), or pamphlets of battery manufacturers.

${ }^{2}$ Figures in brackets indicate the literature references at the end of this paper. applied to studies of the paste wall of dry cells. Characteristics of the paste wall determined in this way are then correlated with the shelf life of the dry cells.

Because of the interaction of the paste wall and other constituents of the dry cell, it would appear that substitutes for the starch-flour paste wall would be the answer to the deterioration of batteries at elevated temperatures. However, other materials have, in general, proved to be even less satisfactory, either because they are corrosive, increase the internal resistance of the cell, exhibit syneresis, or are precipitated or otherwise affected by the cell electrolyte. For this reason, a thorough study of the characteristics of starch-four gels was undertaken and the results are presented in this paper.

The paste wall is made in a number of ways, and various formulas are used in its preparation. In this work a definite formula was rigorously adhered to throughout, so that interpretations of the results could be readily made. The paste walls consisted of approximately $8 \mathrm{~g}$ of zinc chloride, 30 $\mathrm{g}$ of ammonium chloride, $66 \mathrm{~g}$ of distilled water, $0.1 \mathrm{~g}$ of mercuric chloride, and $29 \mathrm{~g}$ of a mixture of cornstarch and wheat flour in a total volume of $108 \mathrm{ml}$. 


\section{Experimental Procedures}

\section{Stability ${ }^{3}$ of Starch Gels in Presence of Dry- Cell Constitutents}

A large number of gels, simulating the paste wall as to composition, were prepared, and after aging their gel strengths were measured by a method previously described [3]. These data served as standards or controls. Then gels were made in like manner in which various constituents of the dry cell were incorporated. The strengths of these were also measured after aging and compared with the standards. Data are given in table 1 for temperatures of $25^{\circ}$ and $54^{\circ} \mathrm{C}$. As starch gels are irreversible, each value represents a single measurement on an individual gel. A temperature of $54^{\circ} \mathrm{C}$ was chosen for the tests, because temperatures this high were encountered in the tropics during the past war. Comparisons of the strengths of gels containing no salts with those that do, show that the zine and ammonium

\footnotetext{
${ }^{3}$ One of the factors affecting the stability of gels is syneresis. Therefore, the syneresis of a large number of gels was measured by the mothod of Chapman and Buchanan [2]. None of the gels presented in this work, whether or not they contained zinc, acetylene black, or $\mathrm{MnO}_{2}$, exuded water over a period of 1 year. Only when the concentration of the cereal in the gels was less than 8 to 9 percent was synersis observed, and this concentration of cereal is much less than that used in the preparation of paste walls of dry cells.
}

chlorides of the dry-cell electrolyte cause a decrease in the strength of starch gels, presumably because of some interaction between these salts and the cereal. Additions of $\mathrm{MnO}_{2}$ or acetylene black, which are insoluble, give an apparent increase in the strength of starch gels, because they contribute to the concentration of the gels as would additional cereal.

Interactions between the paste wall and other constituents of the dry cell are more clearly shown by relative changes in the strength of the gels with time. In figure 1 , the ratios of the strength of aged gels to unaged ones of the same composition, expressed as percentages, are shown as a function of aging or storage time. The figure is largely self-explanatory. All gels decrease in strength as they are aged owing to deterioration of the starch, and the rate is approximately the same for the control gels as for those made with zinc dust or stored in zinc cans, and for those in which acetylene black is incorporated. Consequently, interactions between the paste wall and zinc or acetylene black must be slight. On the other hand, the gels containing no salts decrease in strength less rapidly and those containing $\mathrm{MnO}_{2}$ more rapidly than the standards.

TABLE 1.-Gel strength* measured at $25^{\circ}$ C' of paste walls mixed with constituents of dry cells

\begin{tabular}{|c|c|c|c|c|c|c|c|c|c|c|c|c|c|}
\hline \multirow{2}{*}{ Type of paste wall } & \multicolumn{4}{|c|}{ Composition of paste walla } & \multicolumn{9}{|c|}{ Days of storage } \\
\hline & $\begin{array}{l}\text { Weight, } \\
\text { starch }\end{array}$ & $\begin{array}{l}\text { Weight, } \\
\text { water }\end{array}$ & $\begin{array}{l}\text { Weight, } \\
\mathrm{ZnCl}_{2}\end{array}$ & $\begin{array}{l}\text { Weight, } \\
\mathrm{NH}_{4} \mathrm{Cl}\end{array}$ & 0 & 4 & 7 & 14 & 21 & 30 & 45 & 60 & 90 \\
\hline & $g$ & $g$ & $g$ & $g$ & $\mathrm{~g} / \mathrm{cm}^{2}$ & $\mathrm{~g} / \mathrm{cm}^{2}$ & $\mathrm{~g} / \mathrm{cm}^{2}$ & $\mathrm{~g} / \mathrm{cm}^{2}$ & $g_{:}^{\prime} \mathrm{cm}^{2}$ & $\mathrm{~g} / \mathrm{cm}^{2}$ & $\mathrm{~g} / \mathrm{cm}^{2}$ & $\mathrm{~g} / \mathrm{cm}^{2}$ & $\mathrm{~g} / \mathrm{cm}^{2}$ \\
\hline Control at $25^{\circ} \mathrm{C}$ & 29.20 & 65.67 & 8.13 & 30.27 & 526 & 520 & 520 & 505 & 487 & 481 & 468 & 475 & 480 \\
\hline Control at $54^{\circ} \mathrm{C}$ & 29. 20 & 65.67 & 8.13 & 30.27 & 526 & 520 & 499 & 506 & 482 & 468 & 445 & 461 & 439 \\
\hline $\begin{array}{l}\text { Starch alone without electrolytes at } \\
25^{\circ} \mathrm{C}\end{array}$ & 29. 20 & 88.17 & 0.00 & 0.00 & 671 & 655 & 651 & 649 & 651 & 665 & 641 & 637 & 635 \\
\hline $\begin{array}{l}\text { Starch alone without electrolytes at } \\
54^{\circ} \mathrm{C}\end{array}$ & 29. 20 & 88.17 & .00 & .00 & 671 & 670 & 658 & 656 & 627 & 640 & 634 & 621 & 631 \\
\hline Control +10 grams of $\mathrm{MnO}_{2}$ at $54^{\circ} \mathrm{C}_{-}$ & 28.66 & 64.45 & 7.98 & 29.71 & 916 & & 860 & 778 & 712 & 700 & 630 & $\begin{array}{l}021 \\
621\end{array}$ & 610 \\
\hline $\begin{array}{l}\text { Control }+10 \text { grams of } \mathrm{MnO}_{2}+10 \text { grams } \\
\text { of } \mathrm{Na}_{2} \mathrm{SO}_{4} \text { at } 54^{\circ} \mathrm{C}\end{array}$ & 27.67 & 62.19 & 7. 70 & 28.67 & 927 & & 906 & 840 & 829 & 752 & 691 & & 633 \\
\hline $\begin{array}{l}\text { Control+10 grams of } \mathrm{MnO}_{2}+1.9 \\
\text { grams of borax at } 54^{\circ} \mathrm{C}\end{array}$ & 28.36 & 62.89 & 7. 90 & 29.40 & 886 & & 858 & 809 & 763 & 745 & 644 & 645 & 644 \\
\hline $\begin{array}{l}\text { Control+10 grams of } \mathrm{MnO}_{2}+10 \text { grams } \\
\text { of glucose at } 54^{\circ} \mathrm{C}\end{array}$ & 26.90 & 60.50 & 7. 49 & 27.89 & b 872 & & 589 & 311 & & & & & \\
\hline $\begin{array}{l}\text { Contr ol+10 grams of } \mathrm{MnO}_{2}+10 \text { grams } \\
\text { of dextrose at } 54^{\circ} \mathrm{C}\end{array}$ & 26.90 & 60.50 & 7. 49 & 27.89 & b 877 & & 572 & 285 & & & & & \\
\hline $\begin{array}{l}\text { Control+1 gram of acetylene blacke } \\
\text { at } 54^{\circ} \mathrm{C}\end{array}$ & 28. 66 & 64.45 & 7. 98 & 29. 71 & 551 & 547 & & 505 & & 494 & & & \\
\hline Control in zinc can at $54^{\circ} \mathrm{C}$ & 29. 20 & 65.67 & 8. 13 & 30.27 & 526 & 520 & 508 & $d e 470$ & $\mathrm{~d} \ell 379$ & 463 & 467 & & \\
\hline Control +1 gram of zinc dust at $54^{\circ} \mathrm{C}_{-}-$ & 28.66 & 64.45 & 7.98 & 29.71 & 492 & 485 & -........ & 461 & ......... & 435 & & & 419 \\
\hline
\end{tabular}

a All pastes contained $0.1 \mathrm{~g}$ of $\mathrm{HgCl}_{2}$, which acts as a preservative.

bGassed with evolution of $\mathrm{CO}_{2}$.

c A cetylene black does not wet well. A few drops of butyl cellusolve, a wetting agent, were added.

dAdhesion between zinc and gel was poor.

e12 days.

${ }^{t} 18$ days.

*Weight of mercury divided by area of disk having a diameter of $0.95 \mathrm{~cm}(3 / 8 \mathrm{in}$.). 


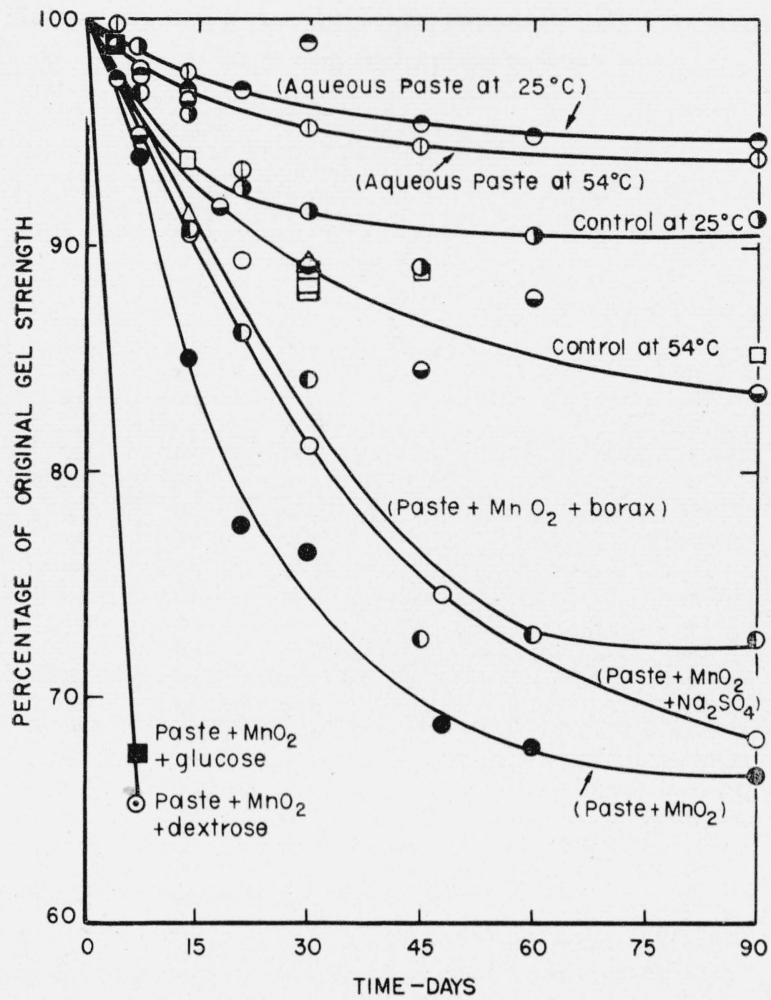

Figure 1.-Percentage decrease in gel stength of cornstarch paste wolls in presence of constituents of dry cells at $25^{\circ}$ and $54^{\circ} \mathrm{C}$.

D. Control at $25^{\circ} \mathrm{C} ; \boldsymbol{\bullet}$, control at $54^{\circ} \mathrm{C}$; $\odot$, starch paste wall without elec trolytes at $25^{\circ} \mathrm{C} ; \Phi$, starch paste wall without electrolytes at $54^{\circ} \mathrm{C}$; control with $10 \mathrm{~g}$ of $\mathrm{MnO}_{2}$ added at $54^{\circ} \mathrm{C}$; $\mathrm{O}$, control with $10 \mathrm{~g}$ of $\mathrm{MnO}$ and $10 \mathrm{~g}$ of $\mathrm{Na}_{2} \mathrm{SO}_{4}$ added at $54^{\circ} \mathrm{C} ; \mathbf{O}$, control with $10 \mathrm{~g}$ of $\mathrm{MnO}_{2}$ and $1.9 \mathrm{~g}$ of borax added at $54^{\circ} \mathrm{C} ; \mathbf{A}$, control with $10 \mathrm{~g}$ of $\mathrm{MnO}_{2}$ and $10 \mathrm{~g}$ of glucose added at $54^{\circ} \mathrm{C}$; $\odot$, control with $10 \mathrm{~g}$ of $\mathrm{MnO}_{2}$ and $10 \mathrm{~g}$ of dextrose added at $54^{\circ} \mathrm{C} ; \triangle$, control with $10 \mathrm{~g}$ of acetylene black added at $54^{\circ} \mathrm{C}$; $\square$, control stored in zinc can or with $1 \mathrm{~g}$ of zine dust added at $54^{\circ} \mathrm{C}$.

Therefore, the salts $\left(\mathrm{ZnCl}_{2}\right.$ and $\left.\mathrm{NH}_{4} \mathrm{Cl}\right)$ and $\mathrm{MnO}_{2}$ apparently react with the cereal causing a decrease in the strength of the gels. $\mathrm{MnO}_{2}$ must react either directly with the starch or its hydrolytic products. When glucose or dextrose, hydrolytic products, are incorporated in starch gels containing $\mathrm{MnO}_{2}$, there is a rapid evolution of $\mathrm{CO}_{2}$ with an attendant large and rapid decrease in the strength of the gel. The decrease in gel strength is caused in part by the fact that the evolution of gas makes the gels porous.

All gels whether or not they contain constituents of the dry cell seem to attain stability within 60 to 90 days, as the decrease in gel strength ceases within this time. Tests for much longer periods of time at $54^{\circ} \mathrm{C}$ could not be made, because gels become desiccated after 4 to 5 months at this temperature. However, the reaction between $\mathrm{MnO}_{2}$ and starch is quite marked during the first 60 days, and the problem resolves itself into finding ways by which this interaction may be either eliminated or retarded. Possible approaches to this problem include (1) the use of addition agents that will retard the hydrolysis of the starch, (2) the use of other types of starch or flour instead of cornstarch or wheat flour, (3) modifications of the starch to decrease its reducing power and hence its interaction with $\mathrm{MnO}_{2}$, (4) the use of the amylose or amylopectin fractions of starch, or (5) the use of the constituents of flour, namely gluten or its protein fractions, rather than the natural flour. Each of these possibilities is considered in the following sections.

\section{Stability of Starch Gels in Presence of Addi- ion Agent and Inhibitors}

Neutral sulfates are believed to retard the hydrolysis of starch [4], and borax is known to increase the viscosity and adhesiveness of starch pastes. However, neither of these salts was effective in retarding the hydrolysis of starch. The slight benefits of these salts indicated in figure 1 are not significant, because these salts raise the strength of starch gels not containing $\mathrm{MnO}_{2}$. Other salts might be used, but in general most addition agents decrease the stability of starch gels and have deleterious effects on dry cells. Therefore, this approach to the elimination of interactions between the paste wall and the constitutents of the dry cell is not promising.

In preparations of the paste wall, mercuric chloride (see formula given in the introduction) is frequently added for the purpose of reducing the local action at the zinc anode. Chromates or chromate films are sometimes used in place of mercuric chloride. Neither amalgamation nor chrome films are as effective as is essential for good shelf-life at high temperatures [5] and other materials have been suggested as inhibitors of the corrosion of zinc. Their choice is largely a matter of trial and error and to study a large number would be a prohibitive task. An elimination may first be made by studying the effects of the inhibitors on the paste wall.

The inhibitors were incorporated into the paste wall by grinding the inhibitor with the starch using a minimum of alcohol, which was then 
allowed to evaporate at room temperature. Heating of an alcoholic-inhibitor-starch mixture causes a decrease in the strength of the starch and was avoided. The starch-inhibitor pastes (pastes $A$ ) were made using the formula given in the introduction, corrections being made for the amount of inhibitor added, so that the ratio of starch to $\mathrm{ZnCl}_{2}, \mathrm{NH}_{4} \mathrm{Cl}$, and $\mathrm{H}_{2} \mathrm{O}$ and the concentrations of $\mathrm{ZnCl}_{2}$ and $\mathrm{NH}_{4} \mathrm{Cl}$ were the same as in the noninhibitor pastes. Data for starch gels containing inhibitors are given in table 2, and for wheat-flour gels containing inhibitors in table 3. Data on pastes (pastes $B$ ) made using the formula given in the introduction without regard to density corrections are given for the starch gels. Data for pastes $A$ and $B$ are not very different.

TABLE 2.-Data showing the effect of inhibitors on the strength of cornstarch gels at $25^{\circ} \mathrm{C}$

\begin{tabular}{|c|c|c|c|c|c|}
\hline \multirow[t]{2}{*}{ Inhibitor } & \multirow{2}{*}{$\begin{array}{l}\text { Grams } \\
\text { of in- } \\
\text { hibitor } \\
\text { per } 100 \\
\text { g of } \\
\text { starch }\end{array}$} & \multicolumn{2}{|c|}{$\begin{array}{l}\text { Weight of } \\
\text { mercury } \\
\text { required to } \\
\text { pull disk } \\
\text { from gels }\end{array}$} & \multicolumn{2}{|c|}{ Gel strength a } \\
\hline & & $\begin{array}{c}\text { Paste } \\
\mathrm{A}^{\mathrm{b}}\end{array}$ & $\begin{array}{c}\text { Paste } \\
\mathrm{B} \circ\end{array}$ & $\begin{array}{c}\text { Paste } \\
\text { A }\end{array}$ & $\underset{B}{\text { Paste }}$ \\
\hline & $g$ & $g$ & $g$ & $\mathrm{~g} / \mathrm{cm}^{2}$ & $\mathrm{~g} / \mathrm{cm}^{2}$ \\
\hline Control .... & 0.00 & 375 & 375 & 526 & 526 \\
\hline $\mathrm{K}_{2} \mathrm{Cr}_{2} \mathrm{O}_{7 \ldots}$ & 1.00 & 431 & -.... & 604 & -...- \\
\hline Do & 2. 00 & 454 & $\ldots$ & 637 & - n \\
\hline Do $\ldots \ldots \ldots$ & 3.00 & 467 잔 & -....... & 655 & -... \\
\hline Do & 5.00 & 481 & & 675 & $\ldots$ \\
\hline $\mathrm{Na}_{2} \mathrm{Cr}_{2} \mathrm{O}_{7} .2 \mathrm{H}_{2} \mathrm{O}$ & 2. 28 & 452 & & 634 & -.... \\
\hline Do & 5. 69 & 479 & $\ldots$ & 672 & ..... \\
\hline$\left(\mathrm{NH}_{4}\right)_{2} \mathrm{Cr}_{2} \mathrm{O}_{7} \ldots$ & 3.00 & 465 & & 652 & $\ldots$ \\
\hline Do & 5.00 & 478 & $\ldots$ & 670 & ..... \\
\hline $\mathrm{K}_{2} \mathrm{CrO}_{4} \ldots \ldots$ & 3.00 & 446 & $\ldots$ & 626 & -.... \\
\hline Do & 5. 00 & 452 & $\ldots$. & 634 & $\ldots$ \\
\hline Do & 10.00 & 404 & $\ldots$ & 567 & -.... \\
\hline $\mathrm{ZnCrO}_{4} \ldots \ldots$ & 5. 00 & 457 & $\ldots$ & 641 & -.... \\
\hline Do & 10.00 & 446 & (n) & 626 & -...- \\
\hline Furfural ....... & 0.50 & 389 & 380 & 546 & 533 \\
\hline Do & 5.00 & 514 & 561 & 721 & 787 \\
\hline Do & 10.00 & 524 & 371 & 735 & 520 \\
\hline Hydrofuramide... & 0.50 & 358 & 362 & 502 & 508 \\
\hline Do & 3.00 & 286 & 309 & 401 & 433 \\
\hline Quinaldine & 2.00 & 395 & 烈 & 554 & ..... \\
\hline \multirow{9}{*}{$\begin{array}{l}\text { Proprietary compounds of un- } \\
\text { known composition. }\end{array}$} & 5. 00 & 361 & - n & 506 & $-\ldots$ \\
\hline & 5.00 & 20 & 33 & 28 & 46 \\
\hline & 5. 00 & 101 & 114 & 142 & 160 \\
\hline & 5.00 & 133 & 143 & 187 & 201 \\
\hline & 5.00 & 176 & 198 & 247 & 278 \\
\hline & 5.00 & 260 & 292 & 365 & 410 \\
\hline & 2.00 & 340 & 355 & 477 & 498 \\
\hline & 5.00 & 318 & 357 & 446 & 501 \\
\hline & 5.00 & 192 & 216 & 269 & 303 \\
\hline
\end{tabular}

a Weight of mercury divided by area of disk having a diameter of 0.95 cm ( $3 / 8$ in.).

b Corrections for densities of constituents of paste were made.

c Corrections for densities of constituents of paste were not made.
TABLE 3.-Data showing the effect of inhibitors on the strength of wheat flour gels at $25^{\circ} \mathrm{C}$

\begin{tabular}{|c|c|c|c|}
\hline Inhibitor & $\begin{array}{l}\text { Inhibitor } \\
\text { per } 100 \mathrm{~g} \\
\text { of flour }\end{array}$ & $\begin{array}{l}\text { Weight } \\
\text { of mer- } \\
\text { cury re- } \\
\text { quired to } \\
\text { pull disks } \\
\text { from } \\
\text { gels a }\end{array}$ & $\begin{array}{c}\text { Gel } \\
\text { strength }\end{array}$ \\
\hline & $g$ & $g$ & $\mathrm{~g} / \mathrm{cm}^{2}$ \\
\hline Control_... & 0.00 & 226 & 317 \\
\hline $\mathrm{K}_{2} \mathrm{Cr}_{2} \mathrm{O}$ & 3.00 & 226 & 373 \\
\hline Do & 5. 00 & 270 & 379 \\
\hline Do....... & 10.00 & 242 & 339 \\
\hline $\mathrm{Na}_{2} \mathrm{Cr}_{2} \mathrm{O}_{7} \mathrm{H}_{2} \mathrm{O}_{\ldots}$ & 3.81 & 278 & 390 \\
\hline Do & 5.69 & 282 & 396 \\
\hline Do & 11. 38 & 252 & 353 \\
\hline$\left(\mathrm{NH}_{4}\right)_{2} \mathrm{Cr}_{2} \mathrm{O}_{7} \ldots \ldots$ & 8.00 & 282 & 396 \\
\hline Do & 10.00 & 276 & 387 \\
\hline $\mathrm{K}_{2} \mathrm{CrO}_{4} \ldots \ldots$ & 3.00 & 241 & 338 \\
\hline Do & 5. 00 & 243 & 341 \\
\hline Do & 10.00 & 229 & 321 \\
\hline $\mathrm{ZnCrO}_{4} \ldots$ & 5.00 & 237 & 332 \\
\hline Do & 8.00 & 249 & 349 \\
\hline Do & 10.00 & 269 & 377 \\
\hline Furfural & 5. 00 & 294 & 412 \\
\hline Hydrofuramide & 5. 00 & 219 & 307 \\
\hline Quinaldine & 5. 00 & 239 & 335 \\
\hline CKM wheat flour ${ }^{c}$ & 0.00 & 259 & 363 \\
\hline \multirow{7}{*}{$\begin{array}{l}\text { Proprietary compounds of unknown } \\
\text { composition. }\end{array}$} & .50 & 258 & 362 \\
\hline & 1.00 & 257 & 360 \\
\hline & 1. 00 & 233 & 327 \\
\hline & 3. 00 & 234 & 328 \\
\hline & 5. 00 & 227 & 318 \\
\hline & 5. 00 & 166 & 233 \\
\hline & 5. 00 & 180 & 252 \\
\hline
\end{tabular}

a Corrections for densities of constituents of paste were made.

b Weight of mercury divided by area of disk having a diameter of $0.95 \mathrm{~cm}$ ( $3 / 8$ in.).

- Treated with methanol; prepared by C. K. Morehouse.

The chromates and dichromates increase the strength of both types of gels, and the increase is about the same for cations $\mathrm{K}^{+}, \mathrm{Na}^{+}, \mathrm{NH}_{4}^{+}$, or $\mathrm{Zn}^{++}$. On the other hand, with the exception of furfural and possibly quinaldine, the other inhibitors (proprietary compounds of unknown composition) lower the strength of gels. This decrease in the strength of starch-inhibitor gels indicates an interaction between the starch and the inhibitor. Dry cells made with paste walls of starch-inhibitor gels were not satisfactory and gave less electrical output than cells without inhibitors [5]. Cells made with furfural and quinaldine, substances which increase the strength of the paste wall, had low flash currents indicating high internal resistance [5].

\section{Paste Walls of Different Starch Types}

Different varieties of starches or flours may function differently as paste walls. Therefore, a number of gels, simulating the paste wall of dry 
cells as to composition, were made with different varieties of starch or flour and aged for 1 day. Their strengths were then measured using disks having a diameter of $0.95 \mathrm{~cm}(3 / 8 \mathrm{in}$.$) . The data$ are given in table 4 and are shown in figure 2 as

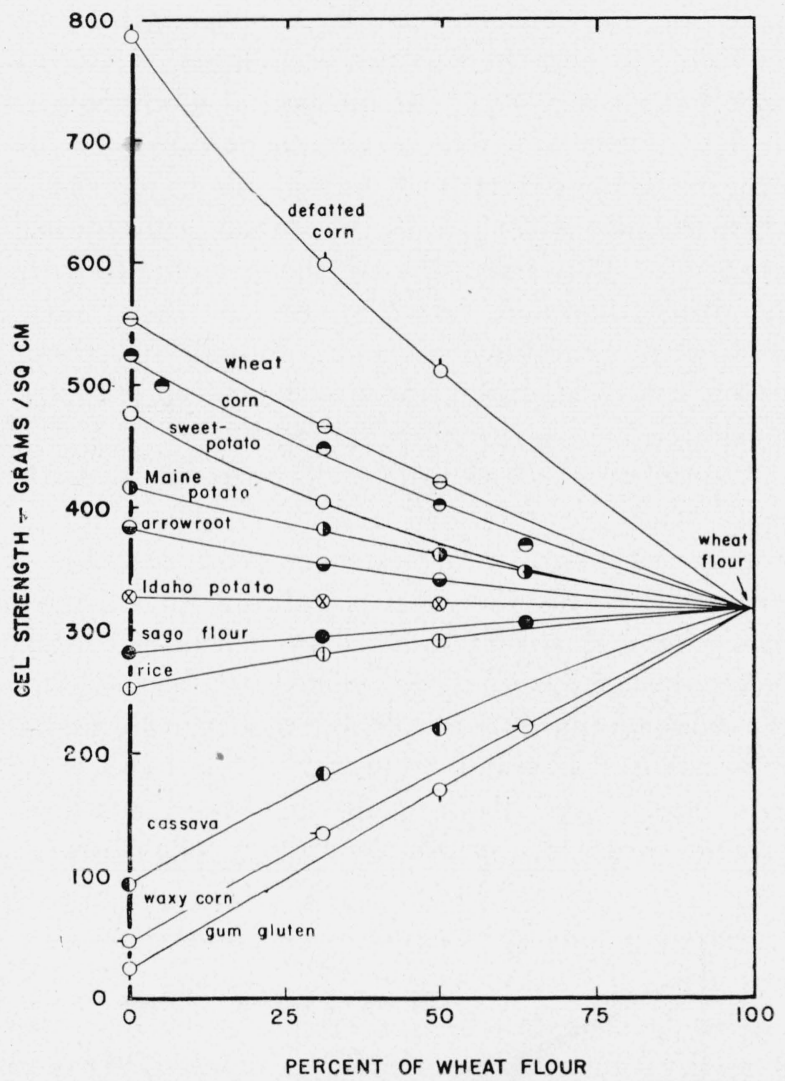

Figure 2.-Gel strengths at $25^{\circ} \mathrm{C}$. of various paste walls as a function of the percentage of wheat flour in the paste wall.

a function of the percentage of wheat flour in the gels. Paste walls of widely different strengths may, therefore, be made by varying the percentage of flour in them or by using different kinds of starch. Very rigid gels are obtained with defatted cornstarch, and nonrigid and tacky gels are obtained with waxy cornstarch. Addition of flour lowers the strength of defatted cornstarch gels and raises the strength of gels made of waxy cornstarch.

In figure 3 the resistance to deformation of gels made of pure starch or flour is shown. The method by which these curves are obtained was described previously [3]. The slope up to the break in the curve gives an indication of the re-
TABLE 4.-Gel strengths at $25^{\circ} \mathrm{C}$ of several standard pastes for construction of dry cells

\begin{tabular}{|c|c|c|c|c|}
\hline Starch or sample & $\begin{array}{l}\text { Weight of } \\
\text { sample }\end{array}$ & $\begin{array}{l}\text { Weight of } \\
\text { wheat } \\
\text { flour }\end{array}$ & $\begin{array}{l}\text { Weight of } \\
\text { mercury } \\
\text { required } \\
\text { to pull } \\
\text { disks } \\
\text { from gels }\end{array}$ & $\begin{array}{c}\text { Gel } \\
\text { strength a }\end{array}$ \\
\hline \multirow{6}{*}{ Cornstarch... } & $g$ & $g$ & $g$ & $\mathrm{~g} / \mathrm{cm}^{2}$ \\
\hline & 29. 20 & 0.00 & 375 & 526 \\
\hline & 26.28 & 2.92 & 356 & 499 \\
\hline & 19. 67 & 9.53 & 320 & 449 \\
\hline & 14. 60 & 14. 60 & 287 & 403 \\
\hline & 9. 53 & 19.67 & 263 & 369 \\
\hline \multirow[t]{2}{*}{ Wheat flour } & 29.20 & -...... & 226 & 317 \\
\hline & 29. 20 & 0.00 & 396 & 555 \\
\hline \multirow[t]{3}{*}{ Wheat starch. . } & 19.67 & 9.53 & 333 & 467 \\
\hline & 14. 60 & 14. 60 & 301 & 422 \\
\hline & 29. 20 & 0.00 & 34 & 48 \\
\hline \multirow[t]{3}{*}{ Waxy cornstarch. } & 19. 67 & 9.53 & 96 & 135 \\
\hline & 9.53 & 19. 67 & 158 & 222 \\
\hline & 29. 20 & 0.00 & 67 & 94 \\
\hline \multirow[t]{3}{*}{ Cassava starch.. } & 19.67 & 9.53 & 131 & 184 \\
\hline & 14. 60 & 14. 60 & 158 & 221 \\
\hline & 29. 20 & 0.00 & 274 & 384 \\
\hline \multirow[t]{3}{*}{ Arrow root starch.. } & 19.67 & 9.53 & 254 & 356 \\
\hline & 14. 60 & 14. 60 & 244 & 342 \\
\hline & 29. 20 & 0.00 & 233 & 328 \\
\hline \multirow[t]{3}{*}{ Idaho potato stareh... } & 19. 67 & 9.53 & 231 & 324 \\
\hline & 14. 60 & 14. 60 & 231 & 324 \\
\hline & 29. 20 & 0.00 & 297 & 417 \\
\hline \multirow{3}{*}{ Maine potato starch } & 19.67 & 9.53 & 273 & 383 \\
\hline & 14. 60 & 14. 60 & 258 & 362 \\
\hline & 9.53 & 19.67 & 248 & 348 \\
\hline & 29. 20 & 0.00 & 340 & 477 \\
\hline \multirow[t]{2}{*}{ Sweetpoteto starch ... } & 19. 67 & 9.53 & 289 & 406 \\
\hline & 9.53 & 19. 67 & 250 & 350 \\
\hline \multirow{3}{*}{ Fice starch. } & 29. 20 & 0.00 & 180 & 253 \\
\hline & 19. 67 & 9.53 & 200 & 281 \\
\hline & 14. 60 & 14. 60 & 208 & 292 \\
\hline \multirow{3}{*}{ Sago flour .... } & 29. 20 & 0.00 & 202 & 283 \\
\hline & 19.67 & 9.53 & 210 & 295 \\
\hline & 9. 53 & 19.67 & 219 & 307 \\
\hline \multirow{2}{*}{ Gum gluten . - } & 29. 20 & 0.00 & 18 & 25 \\
\hline & 14. 60 & 14. 60 & 121 & 171 \\
\hline \multirow{3}{*}{ Defatted cornstarch } & 29. 20 & 0.00 & 561 & 787 \\
\hline & 19. 67 & 9.53 & 428 & 600 \\
\hline & 14. 60 & 14. 60 & 366 & 513 \\
\hline
\end{tabular}

a Weight of mercury divided by area of disk of diameter $0.95 \mathrm{~cm}(3 / 8 \mathrm{in}$.$) .$

sistance a gel offers to deformation. A large slope means that the gel is less rigid than one having a small slope. Thus waxy cornstarch makes paste walls that can be easily deformed, whereas cornstarch gels resist deformation.

To ascertain if the shelf life of dry cells is dependent on the strength of the paste wall, or if the extent of the interactions between the paste wall and dry-cell electrolytes and $\mathrm{MnO}_{2}$ may be different for various varieties of starches, a number of $D$-size dry cells ${ }^{4}\left(1 \frac{1 / 4}{4}\right.$. diameter and $2 \frac{1}{4}$ in. in height) were constructed with paste walls of

${ }^{4}$ See Letter Circular 267, National Bureau of Standards (1941) for a classification of electric dry cells of the Leclanché type. 


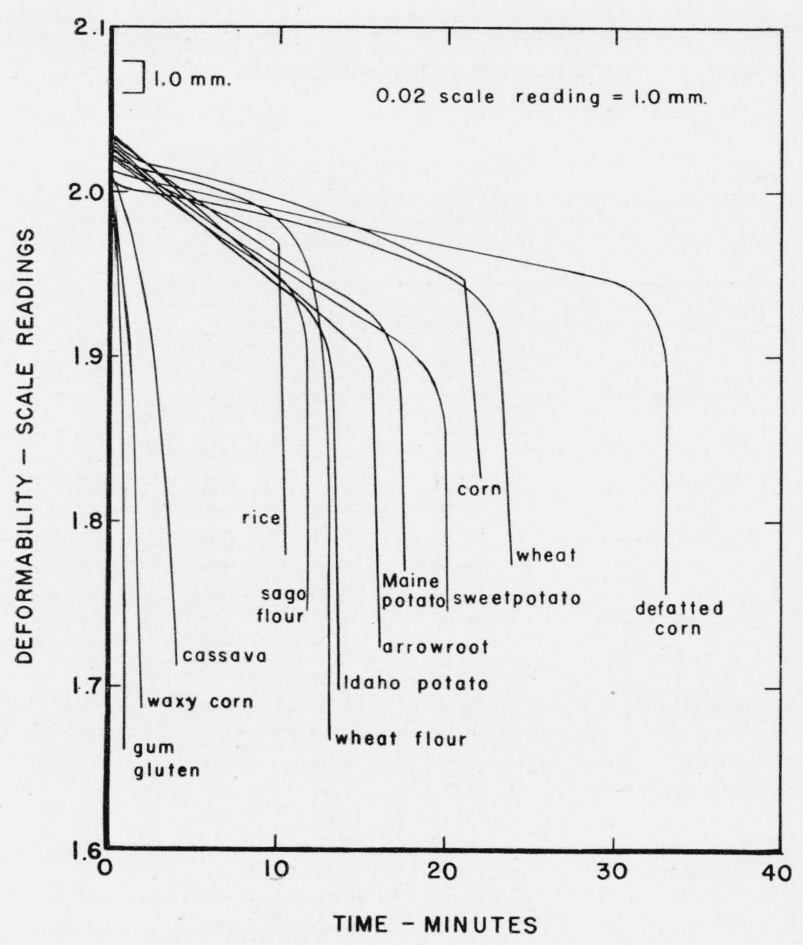

FIGURE 3.-Deformability (scale readings) of paste walls of different starches at $25^{\circ} \mathrm{C}$.

different starch type. Shelf-life data are given in table 5 for a storage period up to 2 years. The data do not indicate that one or another type of starch is preferable for construction of paste walls nor that the interactions between the paste walls and the other constituents of the cell are significantly different for various varieties of starches. Cells with paste walls of waxy cornstarch of low gel strength performed similarly to those with paste walls of cornstarch of high gel strength. Consequently, the shelf life of dry cells is not dependent on the strength of the gel, providing it retains stability. This does not imply that discharge characteristics under various current drains will be the same for different kinds of starch; the data here obtained apply only to shelf life.

\section{Paste Walls of Modified Starches}

In section I, it is shown that natural starches and $\mathrm{MnO}_{2}$ react chemically, and in section II, 3, natural starches of various kinds behave similarly in dry cells. Starch granules consist of chains of glucose residues with primary and secondary alcohol groups, glycol groups, and reducing aldehyde end groups. Reaction of $\mathrm{MnO}_{2}$ and starch may be at any of these groups [6], but it is prob- ably most pronounced at the aldehyde end group. It is possible, therefore, that dry cells with better characteristics would result if the starch used in the paste wall were modified to decrease its reducing power.

A number of modified starches were studied. Each one was characterized by the strength of its gel (table 6) and the resistance each gel offered to deformation (fig. 4). The method of modification of the starch is listed in the second column of table 6 . The strength of starch gels is increased when the fats adsorbed on the starch granules are removed. The strengths of the gels made with the other modified starches are less than those made with unmodified starches. Apparently, most modifications of starch fracture the starch granules causing a decrease in their strength.

A number of $D$-size dry cells were made with paste walls of modified starches. Data for a storage period up to 2 years are given in table 7 for modified starches, and in table 8 for starches plus wheat gluten or fats. Dry cells made with defatted starches and 4601 cornstarch have shelflife data comparable with that of dry cells made with natural starches. On the other hand, dry cells made with paste walls of other modified starches were less satisfactory than cells contain-

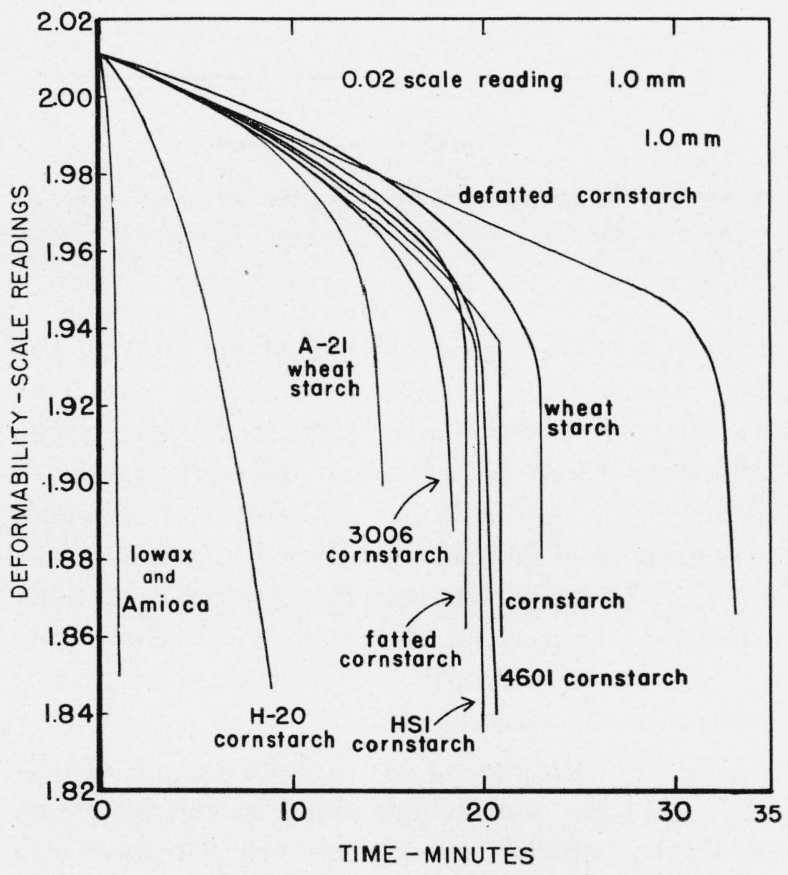

FiguRe 4.-Deformability (scale readings) at $25^{\circ}$ C. of paste walls of different modified starches. 
TABLE 5.- Shelf life data at $21^{\circ} \mathrm{C}$ of D-size dry cells containing different kinds of starches and flours ${ }^{\mathrm{a}}$

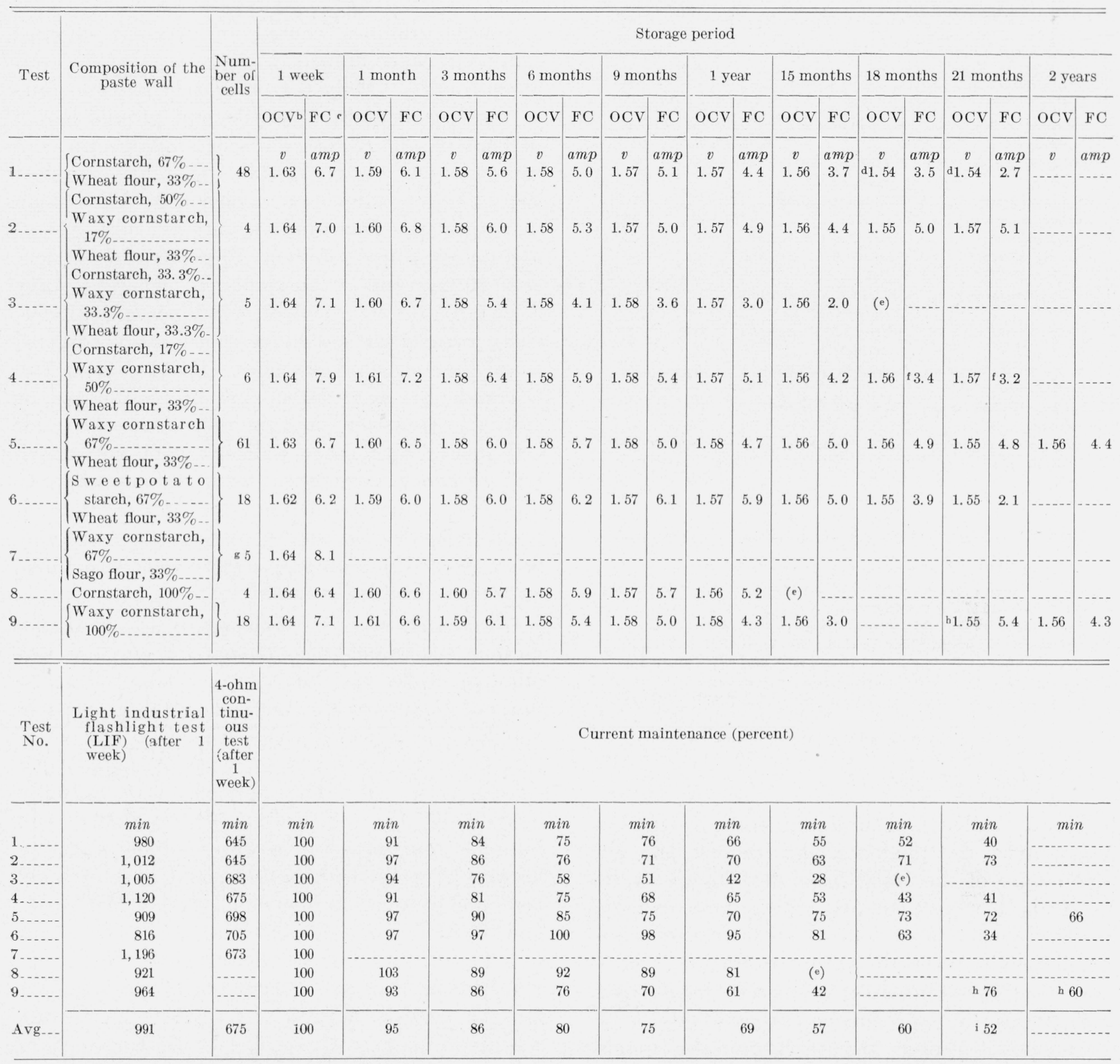

a The data used in constructing this table were supplied by Earl Otto, Clarence K. Morehouse, Jacqueline M. Pritchard, Woodward G. Eicke, Ray Lasky, Frances McPherson, Mary J. Gleason, and Margaret E. Dekle.

b Open-cireuit voltage.

c Flash or short-circuit current.

d 32 cells.

e Scrapped; cells were perforated and gave poor service.

$t$ Perforated.

g All cells were used for the LIF and 4-ohm test.

h 6 cells.

i Does not include the value for test number 9 . 
TABLE 6.-Gel strength of modified starches at $25^{\circ} \mathrm{C}$

\begin{tabular}{|c|c|c|c|}
\hline Starch \& & Modification & $\begin{array}{l}\text { Weight } \\
\text { of mer- } \\
\text { cury }\end{array}$ & $\begin{array}{c}\text { Gel } \\
\text { strength b }\end{array}$ \\
\hline $\begin{array}{l}\text { Natural Buffalo corn- } \\
\text { starch. }\end{array}$ & No modification & $\begin{array}{c}g \\
375\end{array}$ & $\begin{array}{c}\mathrm{g} / \mathrm{cm}^{2} \\
526\end{array}$ \\
\hline $\begin{array}{l}\text { Defatted Buffalo corn- } \\
\text { starch. }\end{array}$ & $\begin{array}{l}\text { Extractions with } 85 \% \text { of } \\
\text { methanol. }\end{array}$ & 561 & 787 \\
\hline $\mathrm{H}-20$ cornstarch ${ }^{\circ}$ & To resist oxidation & 193 & 271 \\
\hline 4601 cornstarch d & do & 356 & 499 \\
\hline 3006 cornstarch d & To resist zinc chloride & 316 & 443 \\
\hline HSI cornstarch e....... & $\begin{array}{l}\text { Treated with chlorine } \\
\text { dioxide. }\end{array}$ & 343 & 481 \\
\hline CKM cornstarch $\&$ & $\begin{array}{l}\text { Mixed with ethanol and } \\
\text { heated at } 80^{\circ} \mathrm{C} \text {. }\end{array}$ & 352 & 494 \\
\hline Soft white wheat starch. & $\begin{array}{l}\text { Slotter and Langford } \mathrm{g} \\
\text { method. }\end{array}$ & 396 & 555 \\
\hline $\begin{array}{l}\text { A-21 wheat starch (Gen- } \\
\text { eral Mills). }\end{array}$ & Unknown treatment.... & 261 & 366 \\
\hline $\begin{array}{l}\text { Fatted Buffalo corn- } \\
\text { starch. }\end{array}$ & $1 \%$ of corn oil added & 327 & 459 \\
\hline $\begin{array}{l}\text { Natural waxy corn- } \\
\text { starch. }\end{array}$ & No modification & 34 & 48 \\
\hline Amioca & do & 30 & 42 \\
\hline Iowax h $\ldots \ldots$ & $\begin{array}{l}\text { Washed with distilled } \\
\text { water. }\end{array}$ & 39 & 55 \\
\hline Amidex (a dextrine) .... & Acid-treated and heated. & 0 & 0 \\
\hline
\end{tabular}

${ }^{8}$ All of the pastes were made with $29.2 \mathrm{~g}$ of starch, $8.133 \mathrm{~g}$ of $\mathrm{ZnCl}_{2}, 30.267$ $\mathrm{g}$ of $\mathrm{NH}_{4} \mathrm{Cl}$, and $65.57 \mathrm{~g}$ of distilled water.

b Weight of mercury divided by area of disk of diameter $0.95 \mathrm{~cm}$ (3/8 in.).

- Supplied by American Maize Products Co., Roby, Ind.

d Supplied by the Corn Products Laboratories, treatments unknown.

e Prepared by H. S. Isbell, National Bureau of Standards.

f Prepared by C. K. Morehouse, formerly of the National Bureau of Standards.

g R. L. Slotter and C. T. Langford, Ind. \& Eng. Chem. 36, 404 (1944).

h Supplied by the Northeastern Regional Laboratory of the U. S. Department of Agriculture, Peoria, Ill.

ing paste walls of natural unmodified starches. Apparently, the modifications fracture the glucose chains of the starch granules, shown by the gel-strength measurements, giving more reducing aldehyde end groups, and consequently increased interaction between the starch and $\mathrm{MnO}_{2}$. Even those treatments intended to convert the aldehyde end groups to nonreducing carboxyl groups [7] must instead fracture the starch granule, thereby giving more instead of less aldehyde end groups. Probably most chemical modifications will affect starch in like fashion. Hence, modified starches will probably be less satisfactory than natural starches for use in dry cells.

Dry cells made with various starches, plus wheat gluten or fats, compare favorably with those prepared with wheat flour, providing the amount of fats or oils added was not excessive. Cells prepared with soybean flour gave less current maintenance than the others, probably because of the large amounts of fats and oils in soybean flour.

\section{Fractionation of Starch}

Starch granules consist of straight chained (amylose) and branched chained (amylopectin) glucose units. Only 0.4 percent of glucose units in amylose contain aldehyde end groups and 4 percent of the glucose units of amylopectin contain aldehyde end groups [8]. Therefore, amylose should be less subject to oxidation by $\mathrm{MnO}_{2}$ than amylopectin. The common starches, corn, wheat, and potato consist of about 20 percent of amylose and 80 percent of amylopectin, whereas waxy cornstarch is 100 percent amylopectin. Hence, waxy cornstarch should be more easily oxidized than the common starches. Otto, Vinal, and Ostrander [1] have shown that this is the case at $100^{\circ} \mathrm{C}$. However, shelf-life data given above for cells made with paste walls of waxy cornstarch and ordinary cornstarch were not appreciably different. However, the amylose content in cornstarch may be too low to expect any noticeable difference. Consequently, $D$-size cells were made with paste walls of corn amylose.

Cornstarch was first defatted by the methanol method of Schoch [9]. Then corn amylose was obtained from the defatted cornstarch by the butanol isoamyl alcohol method of Wilson, Schoch, and Hudson in which a starch paste is first autoclaved for 2 to 3 hours at 18 to 20 pounds per square inch [10]. The amylose was partially dehydrated by tritulation with methanol and butanol, maintained in a water-soluble state by keeping it moist with butanol, and its purity determined by the colorimetric method of McCready and Hassid [11]. A purity of 90 percent was found by this method for the sample by Harriet L. Frush of this Bureau. As this purity was adequate for the present purpose, no further purification was made.

Pastes were made of pure amylose and of mixtures of amylose and cornstarch. The strengths of these pastes are given in table 9, together with data on mixtures of cornstarch and waxy cornstarch. No exact correlation between gel strength and the percentage of amylose in the paste was found. However, it is a question whether these amylose pastes are true gels. Brimhall and Hixon [12] have stated that starches autoclaved at high temperatures possess little rigidity and hence would not form gels. However, when corn amylose, wet with butanol, is heated at $100^{\circ} \mathrm{C}$, it 
TABLE 7.-Shelf life data at $21^{\circ} \mathrm{C}$ of D-size dry cells containing modified starches a

\begin{tabular}{|c|c|c|c|c|c|c|c|c|c|c|c|c|c|c|c|c|c|c|c|c|c|c|}
\hline \multirow{3}{*}{$\begin{array}{l}\text { Test } \\
\text { No. }\end{array}$} & \multirow{3}{*}{$\begin{array}{l}\text { Type of modified } \\
\text { starch }\end{array}$} & \multirow{3}{*}{$\begin{array}{c}\text { Num- } \\
\text { ber } \\
\text { of } \\
\text { cells }\end{array}$} & \multicolumn{20}{|c|}{ Storage period } \\
\hline & & & \multicolumn{2}{|c|}{1 week } & \multicolumn{2}{|c|}{1 month } & \multicolumn{2}{|c|}{3 months } & \multicolumn{2}{|c|}{6 months } & \multicolumn{2}{|c|}{9 months } & \multicolumn{2}{|c|}{1 year } & \multicolumn{2}{|c|}{15 months } & \multicolumn{2}{|c|}{18 months } & \multicolumn{2}{|c|}{21 months } & \multicolumn{2}{|c|}{2 years } \\
\hline & & & OCVb & $\mathrm{FCo}$ & $\mathrm{OCV}$ & FC & $\mathrm{OCV}$ & $\mathrm{FC}$ & $\mathrm{OCV}$ & $\mathrm{FC}$ & $\mathrm{OCV}$ & $\mathrm{FC}$ & $\mathrm{OCV}$ & $\mathrm{FC}$ & $\mathrm{OCV}$ & $\mathrm{FC}$ & $\mathrm{OCV}$ & $\mathrm{FC}$ & $\mathrm{OCV}$ & $\mathrm{FC}$ & $\mathrm{OCV}$ & $\mathrm{FC}$ \\
\hline $10 \ldots$ & Defatted cornstarch & 15 & $\begin{array}{c}v \\
\text { 1. } 63\end{array}$ & $\begin{array}{l}a m p \\
6.5\end{array}$ & $\begin{array}{c}v \\
1.59\end{array}$ & $\begin{array}{c}a m p \\
5.7\end{array}$ & $\begin{array}{c}v \\
1.58\end{array}$ & $\begin{array}{c}a m p \\
5.3\end{array}$ & $\begin{array}{c}v \\
\text { d1. } 57\end{array}$ & $\begin{array}{c}a m p \\
5.7\end{array}$ & $\begin{array}{c}v \\
1.56\end{array}$ & $\begin{array}{l}a m p \\
4.7\end{array}$ & $\begin{array}{c}v \\
\cdot 1.56\end{array}$ & $\begin{array}{l}a m p \\
5.3\end{array}$ & $v$ & $a m p$ & $\begin{array}{c}v \\
\mathrm{e} 1.54\end{array}$ & $\begin{array}{l}a m p \\
4.1\end{array}$ & $\begin{array}{c}v \\
\text { e1. } 54\end{array}$ & $\begin{array}{l}a m p \\
3.5\end{array}$ & $\begin{array}{c}v \\
\text { e1. } 54\end{array}$ & $\begin{array}{r}a m p \\
2.5\end{array}$ \\
\hline $11 \ldots$ & 3006 Cornstarch & 10 & 1. 63 & 6.6 & 1.59 & 6.4 & 1. 58 & 5.3 & 1. 58 & 4.4 & 1. 57 & 4.4 & 1.55 & 3.0 & 1.55 & 2.3 & (f) & $\ldots$ & & & & $-\ldots$ \\
\hline $12 \ldots$ & 4601 Cornstarch & 10 & 1. 64 & 6.7 & 1. 60 & 6.4 & 1. 58 & 5.8 & 1. 58 & 5.4 & 1. 57 & 4. 9 & 1.55 & 4.8 & 1. 55 & 4.3 & 1. 56 & 4.3 & & - & & - \\
\hline $13 \ldots$ & H-20 Cornstarch & 3 & 1.65 & 8.0 & 1. 62 & 5.7 & 1. 59 & 5.8 & 1. 59 & 4.8 & 1. 58 & 4. 6 & 1. 57 & 3.6 & 1. 56 & 3.1 & (f) & & & & & $-\cdots$ \\
\hline $14 \ldots$ & HSI Cornstarch & 5 & 1. 62 & 7.4 & 1. 60 & 6.8 & (f) & & & $\ldots$ & (2) & $\ldots$ & - & -.... & & & - & & & $\ldots$ & & ..... \\
\hline $15 \ldots$ & $\begin{array}{c}\text { H-20 Cornstarch, } \\
67 \% \text {; Wheat flour, } \\
33 \%\end{array}$ & 44 & 1. 62 & 7.5 & 1. 60 & 6.9 & 1. 59 & 6.0 & 1. 58 & 4.1 & 1. 57 & 3.1 & 1. 56 & 2. 6 & 1. 56 & 1.8 & 1. 56 & 1. 2 & $(\boldsymbol{f})$ & & & \\
\hline
\end{tabular}

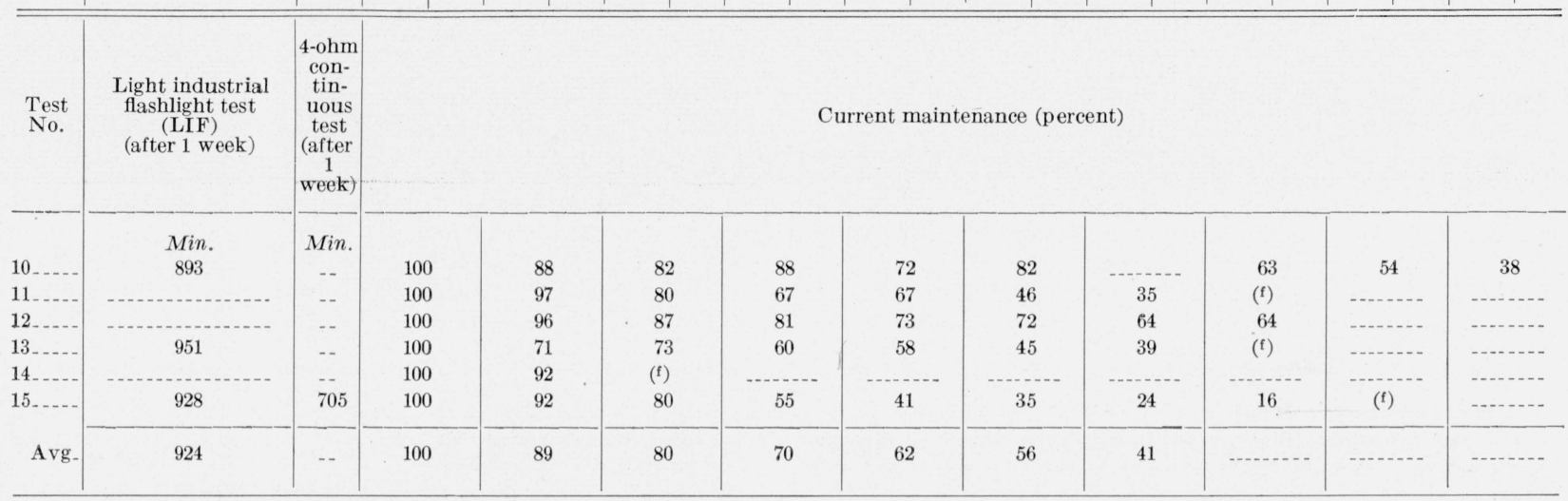

a Data used in constructing this table were obtained by Earl Otto, Clarence K. Morehouse, Jacqueline M. Pritchard, Woodward G. Eicke, and Ray Lasky.

b Open-circuit voltage.

dissolves completely to form a clear solution. On cooling, the amylose appears from solution in the form of a very rigid mass, probably retrograded amylose, which could be used as a paste wall in dry cells.

Data on $D$-size dry cells made with paste walls of corn amylose are given in table 10 . The initial flash or short-circuit current was low, and the current maintenance poor. There are probably two reasons for this poor behavior. First, the amylose must be kept moist with butanol, and second, the amylose pastes are not true gels. Butanol has a deleterious effect on the dry cell, and amylose pastes not being true gels do not retain cell electrolyte well and give up their water and electrolyte to the depolarizing mix of the cell. Attention, therefore, was given to the flour portion of the paste wall.

\section{Fractionation of Flour}

Crude gluten was obtained from wheat flour by the method of Dill and Alsberg [13], in which the
- Flash or short-circuit current.

d 6 cells.

- 4 cells.

i Scrapped; cells were perforated and gave poor service.

starch was washed away with a synthetic tap water of $\mathrm{pH}$ 6.8. The various proteins were then obtained from the crude gluten by a modification of the combined methods of Stockelbach and Bailey [14] and of Haugaard and Johnson [15]. Crude gluten $(200 \mathrm{~g})$ was added to 3.5 liters of $0.1 \mathrm{~N}$ acetic acid to which $7 \mathrm{~g}$ of $\mathrm{K}_{2} \mathrm{SO}_{4}$ were slowly added. After 24 hours of stirring, the glutenin was dispersed with 3.5 liters of 95-percent ethanol. After a few hours the dispersed glutenin was recovered using a laboratory centrifuge $(\mathrm{rpm}=$ $2,000)$. The glutenin became hard and brittle when air-dried and was unsuitable for use in dry cells. After an additional 24 hours at room temperature, a second syrupy mass settled from the acetic acid-alcohol mixture. This fraction was designated mesonin but probably was contaminated with glutenin.

The other proteins were obtained from the supernatant liquid by a cooling process, first for 2 days at $13^{\circ} \mathrm{C}$, next for 1 day at $4^{\circ} \mathrm{C}$, and finally for 2 days at $-10^{\circ} \mathrm{C}$. Syrupy masses were ob- 
TABLE 8.- Shelf life data at $21^{\circ} \mathrm{C}$ of D-size dry cells containing starches plus gluten or fats ${ }^{\mathrm{s}}$

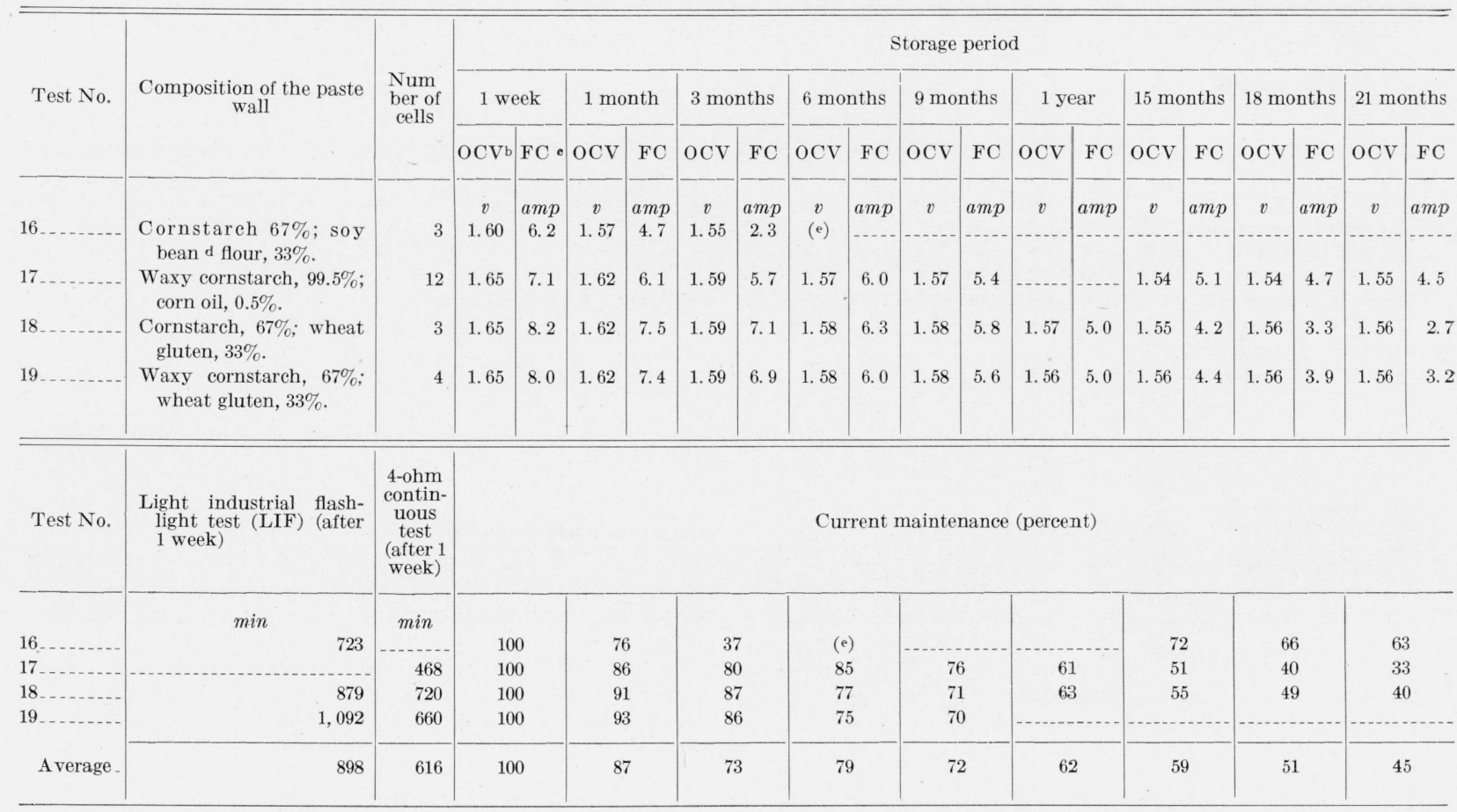

a Data used in constructing this table were obtained by Earl Otto, Clarence K. Morehouse, Jacqueline M. Pritchard, Woodward G. Eicke, and Ray Lasky.

b Open-circuit voltage. c Flash or short-circuit current.

d Contained $46 \%$ fats and oils.

e Scrapped; cells were perforated and gave poor service.
TABLE 9.-Data on the gel strength of aqueous mixtures of cornstarch and corn amylose, and cornstarch and waxy cornstarch

[Moisture contents: Cornstarch $=12.8 \%$; waxy cornstarch $=13.5 \%$; corn amylose $=86.9 \%$ butanol.]

\begin{tabular}{|c|c|c|c|c|c|c|}
\hline $\begin{array}{l}\text { Weight } \\
\text { of corn- } \\
\text { starch }\end{array}$ & $\begin{array}{l}\text { Weight } \\
\text { of corn } \\
\text { amylose }\end{array}$ & $\begin{array}{c}\text { Weight } \\
\text { of } \\
\text { water }\end{array}$ & $\begin{array}{l}\text { Weight of } \\
\text { dry sample } \\
\text { per } 100 \mathrm{ml} \\
\text { of paste }\end{array}$ & $\begin{array}{c}\text { Per- } \\
\text { cent of } \\
\text { amylose }\end{array}$ & $\begin{array}{l}\text { Weight } \\
\text { of } \\
\text { mercury }\end{array}$ & $\begin{array}{c}\text { Gel } \\
\text { strength }\end{array}$ \\
\hline$g$ & $g$ & $g$ & $g$ & & $g$ & $\mathrm{~g} / \mathrm{cm}^{2}$ \\
\hline 11. 50 & 0.00 & 141.0 & 6.7 & 21.0 & 236 & 83 \\
\hline 9.17 & 15. 27 & 126.9 & 6.7 & 34.8 & 463 & 162 \\
\hline 6. 88 & 30.53 & 114.0 & 6.7 & 48. 6 & 526 & 185 \\
\hline 4. 59 & $45.80^{\circ}$ & 101.0 & 6.7 & 62.4 & 682 & 239 \\
\hline \multirow[t]{2}{*}{0.00} & 76.34 & 75.0 & 6.7 & 90.0 & 859 & 301 \\
\hline & $\begin{array}{l}\text { Weight } \\
\text { of waxy } \\
\text { corn- } \\
\text { starch }\end{array}$ & & & & & \\
\hline 12.84 & $\begin{array}{c}g \\
0.00\end{array}$ & 138.4 & 7. 6 & 21.0 & 272 & 95 \\
\hline 9. 63 & 3. 24 & 138.3 & 7. 6 & 15. 7 & 106 & 37 \\
\hline 6.42 & 6.47 & 138.3 & 7. 6 & 10.5 & 34 & 12 \\
\hline 3. 21 & 9. 71 & 138. 3 & 7. 6 & 5. 3 & 13 & 5 \\
\hline 0.00 & 12.95 & 138.3 & 7. 6 & 0.0 & 0 & 0 \\
\hline
\end{tabular}

a Weight of mercury divided by the area of the disk of diameter $1.9 \mathrm{~cm}$ ( $3 / 4$ in.). tained at the end of each day and were, respectively, mesonin I, mesonin II, $4^{\circ} \mathrm{C}$-gliadin, and $-10^{\circ} \mathrm{C}$-gliadin (fraction obtained in last 2 days of cooling). Only a very small fraction (residual gliadin) and insufficient for use in dry cells was was obtained, when the ethanol was removed from the acetic acid-alcohol mixture by distillation. Each fraction was washed with distilled water and used to line $12 D$-size zinc cans by the mere expedient of allowing the pastes to stand in the cans for 12 hours. On pouring the pastes from the cans after 12 hours, a very sticky and adhering film remained on the wall of each can. Part of the $4^{\circ}$ gliadin was neutralized to a phenolphthalein end point with sodium hydroxide. Cells were also made with this neutralized gliadin. Nine $D$-size cells were also lined with a sample of commercial gliadin dissolved in 60-percent ethanol.

Shelf-life data for dry cells made with the various gluten fractions are given in table 10 . The average current maintenance (ratio of flash currents of aged cells to initial flash current of same cells) of the seven types of gluten fractions is given in 
TABLE 10.- Shelf life data at $21^{\circ} \mathrm{C}$ of D-size dry cells made with cornstarch and wheat flour fractions ${ }^{a}$

\begin{tabular}{|c|c|c|c|c|c|c|c|c|c|c|c|c|c|c|c|c|c|c|}
\hline \multirow{3}{*}{ Test No. } & \multirow{3}{*}{\multicolumn{3}{|c|}{$\begin{array}{l}\text { Starch or flour fraction or addition to } \\
\text { paste wall of dry cells }\end{array}$}} & \multirow{3}{*}{$\begin{array}{l}\text { Num- } \\
\text { ber of } \\
\text { cells }\end{array}$} & \multicolumn{14}{|c|}{ Storage period } \\
\hline & & & & & \multicolumn{2}{|c|}{1 week } & \multicolumn{2}{|c|}{1 month } & \multicolumn{2}{|c|}{3 months } & \multicolumn{2}{|c|}{6 months } & \multicolumn{2}{|c|}{9 months } & \multicolumn{2}{|c|}{1 year } & \multicolumn{2}{|c|}{15 months } \\
\hline & & & & & $\mathrm{OCV}^{\mathrm{b}}$ & $\mathrm{FCe}$ & $\mathrm{OCV}$ & $\mathrm{FC}$ & $\mathrm{OCV}$ & $\mathrm{FC}$ & $\mathrm{OCV}$ & $\mathrm{FC}$ & $\mathrm{OCV}$ & $\mathrm{FC}$ & $\mathrm{OCV}$ & $\mathrm{FC}$ & $\mathrm{OCV}$ & $\mathrm{FC}$ \\
\hline $20 \ldots$ & \multirow{5}{*}{\multicolumn{3}{|c|}{$\begin{array}{l}\text { Corn amylose } \\
\text { Pure cornstarch } \\
\text { Cornstarch } 67 \% \text { wheat flour } 33 \% \\
\text { Cornstarch } 67 \% \text { wheat gluten } 33 \% \\
\text { Film of gliadin on zinc can }\end{array}$}} & 2 & \begin{tabular}{c|c}
$v$ & $a$ \\
1.44 &
\end{tabular} & $\begin{array}{r}a m p \\
4.8\end{array}$ & $\begin{array}{c}v \\
1.38\end{array}$ & $\begin{array}{l}a m p \\
1.8\end{array}$ & $\begin{array}{c}v \\
(\mathrm{~d})\end{array}$ & $a m p$ & $v$ & $a m p$ & $v$ & $a m p$ & $v$ & $a m p$ & $v$ & $a m p$ \\
\hline $21 \ldots$ & & & & 13 & 1.64 & 7.1 & 1. 59 & 6.8 & 1. 58 & 6.7 & 1. 57 & 6.3 & 1.56 & 5.9 & 1. 56 & 5.3 & & \\
\hline $1 \ldots \ldots$ & & & & 48 & 1.63 & 6.7 & 1. 59 & 6.1 & 1. 58 & 5.6 & 1.58 & 5.0 & 1.57 & 5.1 & 1. 57 & 4.4 & 1.56 & 3.7 \\
\hline $18 \ldots \ldots$ & & & & 3 & 1.65 & 8.2 & 1.62 & 7.5 & 1. 59 & 7.1 & 1. 58 & 6.3 & 1.58 & 5.8 & 1. 57 & 5.0 & 1.56 & 3.9 \\
\hline $22 \mathrm{e}_{\ldots} \ldots \ldots$ & & & & 9 & 1.66 & 4. 9 & 1.62 & 4.8 & 1. 58 & 4. 9 & 1.57 & 5.0 & f 1.56 & 3.6 & f 1.57 & 4. 1 & f 1.55 & 4.2 \\
\hline & \multicolumn{3}{|c|}{$\begin{array}{l}\text { Film of neutralized } 4^{\circ} \text { gliadin on zine } \\
\text { can. }\end{array}$} & 6 & 1.65 & 7.9 & 1. 60 & 7.4 & 1. 58 & 7.0 & 1. 56 & 6.9 & g1. 55 & 6.8 & g1. 56 & 6.3 & 1. 57 & 5. 9 \\
\hline $24 \mathrm{e}_{\ldots} \ldots$ & \multirow{2}{*}{\multicolumn{3}{|c|}{$\begin{array}{l}\text { Film of }-10^{\circ} \text { gliadin on zine can } \\
\text { Film of } 4^{\circ} \text { gliadin on zine can }\end{array}$}} & 7 & 1. 66 & 6.6 & 1. 62 & 6.2 & & & 1. 56 & 6.1 & 1. 56 & 5.7 & 1. 56 & 5.7 & 1. 57 & 5.5 \\
\hline & & & & 5 & 1.66 & 4.8 & 1. 62 & 4. 9 & & & 1.57 & 4.2 & 1. 56 & 4.5 & 1. 57 & 4.5 & 1. 57 & 4. 2 \\
\hline $26 \mathrm{e} \ldots \ldots$ & \multicolumn{3}{|c|}{ Film of mesonin on zine can } & 9 & 1.66 & 6.2 & 1.62 & 5. 8 & 1. 58 & 5.6 & 1. 56 & 4.9 & 1. 56 & 4.3 & ${ }^{\mathrm{f}} 1.57$ & 5.0 & ${ }^{\mathrm{f}} 1.57$ & 4.4 \\
\hline $27 \mathrm{e} \ldots \ldots$ & \multirow{2}{*}{\multicolumn{3}{|c|}{$\begin{array}{l}\text { Film of mesnin I on zine can } \\
\text { Film of mesonin II on zinc can }\end{array}$}} & 9 & 1.65 & 5.7 & 1. 62 & 5.4 & 1. 58 & 5.0 & 1. 57 & 4.8 & h1. 56 & 3.8 & (d) & & & \\
\hline $28 \mathrm{e} \ldots \ldots \ldots$ & & & & 2 & 1.65 & 5.7 & 1. 60 & 5.2 & 1. 58 & 5. 2 & 1. 57 & 4.7 & (i) & (i) & (i) & (i) & (i) & (i) \\
\hline \multirow{2}{*}{ Test No. } & \multicolumn{2}{|c|}{$\begin{array}{l}\text { Light industrial flashlight test } \\
\qquad(\mathrm{LIF})\end{array}$} & \multirow{2}{*}{\multicolumn{2}{|c|}{$\begin{array}{l}\text { 4-ohm continu- } \\
\text { ous test } \\
\text { (1 week) }\end{array}$}} & \multirow{2}{*}{\multicolumn{14}{|c|}{ maintenance (percent) }} \\
\hline & 1 week & 6 months & & & & & & & & & & & & & & & & \\
\hline & Minutes & Minutes & \multicolumn{2}{|c|}{ Minutes } & \multirow{2}{*}{\multicolumn{2}{|c|}{100}} & & & & & & & & & & \\
\hline $\begin{array}{l}20 \ldots- \\
21 \ldots\end{array}$ & 921 & (n) & \multirow{4}{*}{\multicolumn{2}{|c|}{$\begin{array}{l}645 \\
720\end{array}$}} & & & $\begin{array}{l}3 \\
9\end{array}$ & 86 & $\begin{array}{r}(d) \\
9\end{array}$ & 94 & $8 !$ & & 83 & 3 & 75 & 5 & & \\
\hline $1 \ldots$ & 980 & & & & \multicolumn{2}{|c|}{$\begin{array}{l}100 \\
100\end{array}$} & 9 & 1 & 8 & 34 & 75 & & 76 & & 66 & 6 & & 55 \\
\hline 18 & 879 & . & & & 100 & & 9 & 1 & 87 & 37 & 77 & & 71 & 1 & $t_{61}$ & & i 5 & 51 \\
\hline $22 \ldots$ & 808 & 794 & & & 100 & & 9 & 8 & 100 & 0 & 102 & & g 73 & & g 84 & & & 94 \\
\hline $23 \ldots \ldots$ & 767 & 777 & & & 100 & & 9 & 4 & 8 & 39 & 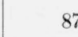 & & 86 & 6 & 80 & 0 & & 75 \\
\hline $24 \ldots \ldots$ & 802 & 746 & & & 100 & & 9 & 4 & & & 92 & & 86 & 6 & 86 & 6 & & 83 \\
\hline $25 \ldots \ldots$ & 837 & 841 & & & 100 & & 10 & & .. & & 88 & & 94 & 4 & j 94 & & & 88 \\
\hline $26 \ldots$ & 716 & 753 & & & 100 & & 9 & 4 & 9 & 90 & 79 & & 69 & 9 & 81 & 1 & & 71 \\
\hline $27 \ldots \ldots$ & 879 & 747 & & & 100 & & 9 & 5 & 8 & 88 & 84 & & $\mathrm{~h} 67$ & & & & & \\
\hline $28 \ldots$ & 919 & 720 & & & 100 & & 9 & 1 & 91 & & 82 & & (i) & & (i) & & & (i) \\
\hline $\begin{array}{l}\text { Avg of } 22 \text { to } \\
28 \text {. }\end{array}$ & 814 & 767 & & & 100 & & 9 & 5 & 92 & & 87 & & 79 & & 85 & 5 & & 79 \\
\hline
\end{tabular}

a Data used in constructing this table were obtained by Clarence $\mathrm{K}$. Morehouse and Jacqueline M. Pritchard.

b Open-circuit voltage.

c Flash or short-circuit current.

d Scrapped; cells gave poor service.

e All cells contained a paste wall of cornstarch, $67 \%$ and wheat flour, $33 \%$.
${ }^{f}$ Data for 7 cells; 2 cells were removed for LIF tests.

g Data for 4 cells; 2 cells were removed for LIF tests.

h Perforated.

i Removed for LIF tests.

j Value not included in average.

cells reported here, but identical procedures were followed in making all of the cells reported in this paper, and comparisons must be made with the experimental cells and not with commercial ones. It is known that gluten and its protein fractions are inhibitors of the corrosion of zinc [5], and their beneficial effects in the dry cells may be interpreted in this light. Therefore, the properties of the paste wall of dry cells may be improved, not by changes in the starch content, but by changes in the flour content wherein the protein constituent is either modified or used as a film. 


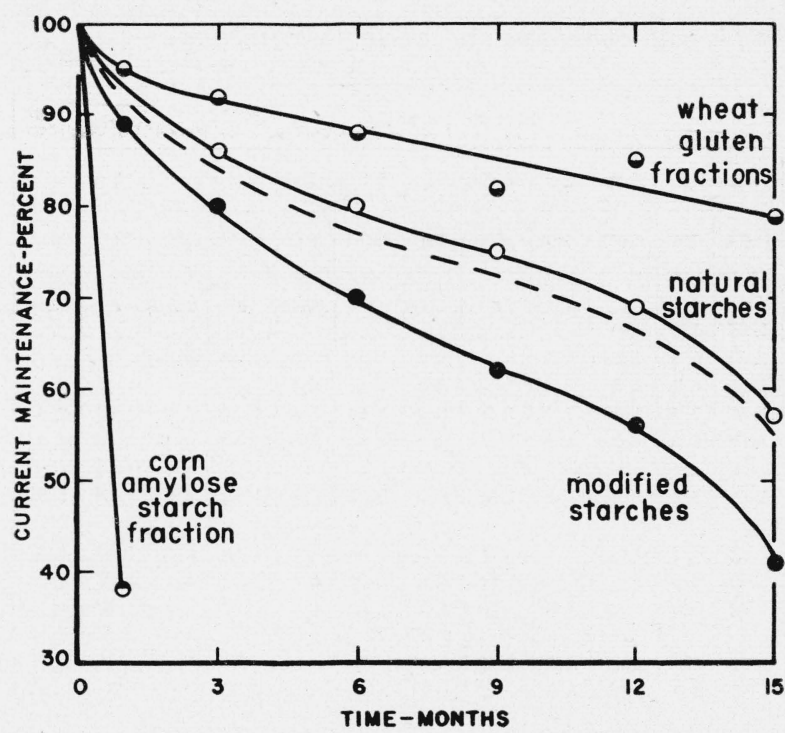

Figure 5.--Current maintenance of D-size flashlight cells stored at $21^{\circ} \mathrm{C}$ and made with paste walls of natural starches, modified starches, and gluten fractions.

๑, 7 gluten fractions (45 cells); $\bigcirc, 8$ starch-flour combinations (169 cells); -, 5 modified starches (42 cells); , $\odot$ amylose (2 cells); _ _ _-, cornstarchwheat flour (48 cells).

\section{Conclusions}

The results of this investigation have shown that the paste walls of dry cells react for a time with the depolarizing mix of manganese dioxide, and to a lesser degree with the zine and ammonium chlorides of the electrolyte. It was shown that these reactions could not be eliminated or curtailed by using different varieties of starches, modified starches of low reducing power, starch fractions of low reducing power, or by the use of addition agents. Improvements in dry cells could be made, however, by using protein films on the surface of the zinc anode of a dry cell. These films decrease the local action at the anodes whereby the gassing and the drying out of the dry cell and the desiccation of the paste wall are retarded. This suggests that these latter factors are more critical than the deterioration, or the interaction of the paste wall with the constituents of the dry cell, in determining the shelf life of dry batteries in hot and humid climates.

Acknowledgment is gratefully given to George W. Vinal for his interest and suggestions during the course of this investigation, to Harriet L. Frush for the determination of the purity of amylose, to H. S. Isbell for the preparation of a modified starch, and to Earl Otto and C. K. Morehouse and their associates for many of the electrical measurements reported in this paper.

\section{References}

[1] E. Otto, G. W. Vinal, and E. Ostrander, Trans. Electrochem. Soc. 86, 235 (1944).

[2] O. W. Chapman and J. H. Buchanan, Iowa State College, J. Sci. 4, 441 (1930).

[3] W. J. Hamer, J. Research NBS 39, 29 (1947) RP1810.

[4] E. Angelescu and O. Manolescu, Bul. Soc. Chim. Romania 11, 99 (1930).

[5] C. K. Morehouse, W. J. Hamer, and G. W. Vinal, J. Research NBS 40, 149 (1948) RP 1863.

[6] G. Felton, F. F. Farley, and R. M. Hixon, Cereal Chem. 15, 678 (1938).

[7] H. S. Isbell. Unpublished.

[8] K. H. Meyer, Advances in colloid science, p. 162, edited by E. O. Kraemer (Interscience Pub. Inc., New York, N. Y., 1941).

[9] T. J. Schoch, J. Am. Chem. Soc. 60, 2824 (1938).

[10] E. J. Wilson, Jr., T. J. Schoch, and C. S. Hudson, J. Am. Chem. Soc. 65, 1380 (1943).

[11] R. M. McCready and W. J. Hassid, J. Am. Chem. Soc. 65, 1154 (1943).

[12] B. Brimhall and R. M. Hixon, Ind. Eng. Chem., Anal. Ed. 11, 358 (1939).

[13] D. B. Dill and C. L. Alsberg, Cereal Chem. 1, 222 (1924).

[14] L. S. Stockelbach and C. H. Bailey, Cereal Chem. 15, 801 (1938).

[15] G. Haugaard and A. H. Johnson, J. Biol. Chem. 93, 677 (1931).

Washington, October 7, 1947. 